\title{
Research on Difficult Family Environment and Inequality of Opportunities for Children's health: evidence from seven provinces across China
}

\section{Benfeng Du}

Renmin University of China

\section{Xuan Wang}

Renmin University of China https://orcid.org/0000-0001-8094-9643

Yuexuan Mu ( $\triangle$ muyuexuan0331@163.com )

Renmin University of China

\section{Research}

Keywords: Difficult family environment, Child health, Shapely Value Decomposition, Influencing factors and contributions, inequality of opportunity

Posted Date: September 23rd, 2020

DOl: https://doi.org/10.21203/rs.3.rs-78032/v1

License: (c) (i) This work is licensed under a Creative Commons Attribution 4.0 International License. Read Full License 


\section{Abstract}

\section{Background}

Family is an important environment for the adaptive development of children. A lack of family functions can affect the equality of children's access to health opportunities. Based on past survey data, there are many children in difficult families in China, and the life experiences of living in difficult families have had a serious negative impact on children's health. Therefore, the research on health equality in children in difficult families is particularly important.

\section{Objective}

The study aimed to examine the difference in the extent of family environment's influence on equal health opportunities between children from difficult families and ordinary families.

\section{Method}

The study based on data of a survey, "Health Status of Children in Difficult Families," which was conducted in 7 provinces in China in 2018. The D index was used to calculate the extent to which the family environment influenced the health opportunity equality in children from two types of families. Through conducting the Shapley decomposition based on ordered multi-class regression, the relative level of contribution of different family environment factors to the health opportunities equality in children from two types of families was examined.

Results

The family variables included in this paper examined had a significant impact on the health opportunities of children from both families, and they had a greater impact on children's mental health. Based on the results of Shapley decomposition on different family environment factors, the family relationship had the greatest impact on the self-reported health opportunities of children from difficult families $(32.02 \%)$. Living condition was the main factor that influenced the self-reported health opportunities of children from ordinary families (25.72\%). In terms of mental health, family economic status was the main factor that affected the mental health opportunity equality in children from difficult families (21.22\%). Family relationship was the main factor influencing the mental health opportunity equality in children from ordinary families (36.54\%). In terms of cognition, family relationship was the main factor affecting health opportunity equality in children from two types of families ( $55.72 \%$ and $28.05 \%$, respectively).

\section{Conclusion}

There is a significant difference in the extent to which the family environment influences the health opportunity equality between children from two types of families across different health domains. Family relationship is the most important factor affecting the fairness of children's access to health opportunities in difficult families. 
Full Text

This preprint is available for download as a PDF. 